UDK 821.161.2-3.09+821.162.1-3.09

DOI $10.15421 / 462006$

\title{
POSTMODERN NON-LAUGHTER IRONY IN OŚCI BY I. KARPOWICZ AND FRUTCHEN BY T. HAVRYLIV
}

\author{
I. Kropyvko \\ Doctor of Philology, Associate Professor, \\ Department of Ukrainian Literature, \\ Oles Honchar Dnipro National University \\ irina_kropyvko@ua.fm \\ orcid.org/0000-0002-9648-8340 \\ O. Budilova \\ Associate Professor, Department of English Philology, \\ Oles Honchar Dnipro National University \\ sasha.budilova@gmail.com \\ orcid.org/0000-0002-5143-1375
}

Introduction. Irony and laughter in postmodern carnival prose are interrelated, yet not interdependent. Irony in postmodern literature has become an academic focus in the works by such renowned scholars as J. Baudrillard, G. Deleuze, J. Derrida, U. Eco, D. Fokkema, I. Hassan, L. Hutcheon, F. Jameson, J.-F. Lyotard etc. Ukrainian scholars focusing on this topic include S. Geiko and R. Semkiv, while among Polish scholars, it is worth mentioning B. Baran, A. Doda, M. Markovsky, Z. Mitosek, M. Novak. Irony is traditionally defined through its laughter-causing trend (Zozulya, 2014: 78); however, postmodern irony can be not funny. Its predominating feature is meaning ambiguity resulting from the gap between pronounced and non-pronounced.

Irony is traced not only as part of meaning-shaping at the content level. Mark Andrychyk argues that "to postmodern irony, it is not just an artistic message that matters, but also a code, which takes up the function of a narrative focus. In this case, a special emphasis is placed on a language game, whereby the idea is split into incompatible fragments and separate elements gain meaning" (Andrychyk, 2014: 72). Moreover, a big deal of importance belongs to an intertextuallyformal aspect of irony as a stylistic device and expression of the overall postmodern ironic mind. The truth is that literature reached its limits together with "the end of history", and, accordingly, art's experimental potential was exhausted. Hence, the purpose of the article is to trace the narrative forms of the ironic game's domination as a narrative pattern and composition principle of the prose by postmodern writers.

The research employs the methods of narrative analysis and receptive aesthetics.

Results and discussions. In light of this, let us look at irony used by Ignacy Karpowicz in one of the episodes of his Ości (Fish Bones). But first, let us touch on the title of the novel, which sounds extraordinary and ironic, or even ironically extraordinary. If we lean on their dictionary meaning, fish bones (or awns) can hardly become a good title for the novel counting 469 pages. Another way to find the title explanation is to resort to phraseological units. Three options come to mind: pain in the neck (stać ością w gardle), that is, something that really disturbs; there is no fish without bones (nie ma chleba bez ości, nie ma ryby bez kości), which can be interpreted in relation to the novel as the fact that pleasures always come with something unwanted; if you fest, do not look for bones in the bread (kiedy się kto przepości, nie szuka w chlebie ości), which may be applicable to the novel in a sense that there's no point in looking for something where it is not supposed to be, in other words, not to take things too seriously. All three phrases may be applicable to the novel, as it depicts characters' emotions, describes things that hinder them from feeling good and things they hide from themselves and others. The novel cannot be reduced to one idea, as it represents phantasms that accompany people in their everyday life.

We can take a different approach - to be more specific, different approaches to title decoding. If we take this phrase metaphorically, we can agree with P. Czaplinski's idea that Fish 


\section{Ukrainian sense. 2020. ISSN 2313-4437}

Bones is a novel about the social skeleton flexibility, which grows over time. He believes that dynamic society gives new meanings to ancient abstract notions which end in "ość"; love (miłość), responsibility (odpowiedzialność), kind-heartedness (lojalność) are subject to practical redefinitions regardless of the ideological unity (Czapliński, 2013).

Once the novel appeared, literary criticism had another observation connected with its graphic design. A literary criticist under a pen-name (ak) paid attention to the fact that the words on the title page are written with small letters. This gave him an idea that the text contains boneless characters (k-ości), describes modern realia (współczesn-ości), provides a lot of opportunities (możliw-ości), presents a dependence mechanism (zależn-ości), daily contradictions (sprzeczności), a lot of identities (tożsam-ości) and personalities (osobow-ości), as well as an eternal need in love (mił-ości) and intimacy (blisk-ości); as a result, we get a peculiar range of polysemy (wieloznaczn-ości) ((ak), 2013).

As we can see, the novel title's polysemy strictly follows U. Eco's recommendations (the title should confuse the reader and encourage various interpretations (Eco, 2000: 598). I. Karpowicz goes even farther than the Italian scholar, as his polysemy turns into non-pronounced, a leftover of verbalized, into "ness" ("ość"): "Powietrze czy nie-, wnętrze czy zewn-, tak czy siak skręczał ją pusty, zbędny ból, jakaś -ość bez tematu" (Karpowicz, 2014: 118).

The plot of the episode randomly chosen for analysis is the following: thirty-six-year-old Maya, who is in low spirits as she has lost her job and suspects her husband of a love affair, comes to an interview. Her state unfolds on 12 pages, where the narrator describes her thoughts and feelings reproducing specific imagery and logic (no logic) behind the heroine's thinking shaped/transformed by the modern culture. An ironic effect is created through hints, understatements, unexpected approaches to representation. The reader has to follow narrator's picture to read the woman's "true" story.

This situation perfectly fits the women's fiction formula, but the author deviates from conventional ways of the empathetic depiction of a suffering woman's inner world. The reader is exposed to a detailed picture of the heroine's thinking and self-analysis, her emotional instability. The author seems to be kidding at the techniques innate in formula-based genres, inheriting them and breaking stereotypes at the same time. Particularly, he visualizes and illustrates creative thinking and inner speech. It is not just an author's indirect speech or the heroine's stream of consciousness, it is ironizing over them as narrative devices, for instance: "Dojrzała, żeby zadać sobie pytanie z gatunku “dlaczego?”, podgatunek “czemu ja?”, kategoria "ach”. // Dlaczego i czemu ja. Ach"2 (Karpowicz, 2014: 114). Or: "Tyle już razy Maja przerabiała osunięcie się w rozpacz i depresję, że drogę tę zapamętała"3 (Karpowicz, 2014: 114], "Chodź, Sławoj, dam ci skórkę od ziemniaka. Poprawił mi się gumor"4 (Karpowicz, 2014: 116).

Sometimes this "narrative" irony is combined with irony over contemporary trends in literary studies, for instance, psychoanalysis, or with irony over postmodern philosophical discussions about reducing boundaries between internal and external: "Bardzo ją ten stan bolał: to, że jest pusta i niepotrzebna w środku oraz że ta pustka i niepotrzeba przyszły z zewnątrz, doprowadzając do sytuacji, w której to Maja nigdzie się nie mieściła. Nie było jej w sobie, nie było jej na zewnątrz siebie" "Karpowicz, 2014: 117). The narrator is presented as a highly educated person well-aware of cultural trends, which is proved by his deviating the topic, to be more specific, a sort of insertions - introductory words to a new situation, particularly his speculations on the dual physiological and cultural nature of human beings: "Wbrew przesądom i naukom każdy z nas ma dwie matki i często ani jednego ojca. Matka pierwsza to Natura. Matka druga to Kultura. Matka

\footnotetext{
${ }^{1}$ The air either no-, inner or out-, this or that way twisted her empty, outrageous pain, some themeless "ness".

${ }^{2}$ Mature enough to ask myself "why?", of "why me?" type from the "Ah" category. // Why me. Ah.

${ }^{3}$ Maya would so often fall into despair and depression that she clearly remembers her way there.

${ }^{4}$ Come to me, Slavoy, I'll give you a potato skin. I've regained humor.

${ }^{5}$ This state was really disturbing: she is totally empty and unnecessary from the inside, on one hand, and on the other, this emptiness and unnecessarity found her from the outside where Maya is found nowhere. She was neither inside, nor outside of herself.
} 


\section{Ukrainian sense. 2020. ISSN 2313-4437}

pierwsza nigdy nie kłamie... <..> Matka druga jest wyrozumiała, mieszka nieco bardziej na zewnątrz, prowadzi schronisko dla swoich dzieci, dla osób pokrzywdzonych przez pierwszą matkę. Matka druga tka miraże, częstuje karmelkami, uczy, że warto uciekać przed prawdą emocji, odruchów, dresczy... <..> Matki zazwyczaj żyją w zgodzie, lecz bywa i tak, że skaczą sobie do gardeł. Walczą jak suki. Areną walki zawsze jest ich wspólne dziecko. Którakolwiek z matek by wygrała, zawsze przegrywa arena. Arena odnosi rany, niekiedy odgryza paznokcie do krwi, nacina żyletką wnętrze ud, zapomina o spuszczeniu wody w toalecie, lunatykuje"6 (Karpowicz, 2014: 121122). This vast and stylistically ambivalent introduction was necessary to outline Maya's anxiety. To avoid descriptions, the narrator refers to the heroine as to arena where her two mothers fight. This definition is divided into two parts within one paragraph, thanks to which the reader returns to the narrator's philosophical speculations twice in their thought, which enhances the ironic and humorous effect of the generally serious situation.

To describe his characters, the author often resorts to the terms popular in contemporary cross-cultural studies. For instance, the condition of Shimon, Maya's loneliness-seeking husband, at the point when someone sat on the bench next to him, is described through the terms of psychoanalysis, linguistics and environmental awareness, which is logical due to the fact that Shimon is a linguist, and his wife is a biologist, and testifies to the impact of marriage and professional life on a person's self-description vocabulary: "Ktoś obok przysiada na ławce, Szymon pospiesznie wciąga $\mathrm{w}$ siebie szybującą świadomość, być może nawet $\mathrm{z}$ przedrostkiem samo-, wciąga jak oddech, jak mrówkolew mrówkę, do więzienia, do leju. Jest teraz ponownie kompletny, ponownie w niekomfortowej i oswojonej celi - tylko stąd, z niej, z tego niedosłownie okratowanego miejsca, z tego siebie samego potrafi komunikować się z innymi ludźmi"”7 (Karpowicz, 2014: 105).

However, not all cases of irony have to do with the way artistic information is presented to the reader. I. Karpowicz ironizes over irony as such. Irony usually highlights a phenomenon's distinction from the way it is normally understood. The novel questions exactly the concept of a norm, and for Maya's family, the norm is something that society considers abnormal. Feeling guilty for insufficient care for her adolescent son, Maya decided to make him breakfasts. Three days prior to this, her son had asked her not to do that because these breakfasts did not benefit him. On the fourth day, "zaspany Bruno wszedł do kuchni, spojrzał na pusty stół i się uśmiechnął. Uśmiechnął, jak gdyby wszystko wróciło do normy" (Karpowicz, 2014: 113). The overall choice of characters testifies to the author's irony over plot development. For instance, one of them - Norbert - is described by P. Czaplinski as follows: "He is a non-practicing racist particularly obsessed with Asians who he considers subhumans. In addition, he is a homophob, who considers gays perverts, and himself - a heretic sleeping with men. Until he had an affair with Ninel, he had been a womanhater. Yet, he has homosexual relationships with a Vietnamese, and at some point, he had an affair with a feminist" (Czapliński, 2013).

In postmodernist fiction, irony usually appears to be ambiguous and multidimensional. One line penetrates the text surface, in which case the reader can enjoy irony. It is expressed through linguistic means. Irony markers seem to be located on the surfers, just like in the previously analyzed text. The second one is obscure and targets a "professional" reader. The ironic effect is

\footnotetext{
${ }^{6}$ Despite the prejudice and dogmas, each one of us has two mothers and often no father. The first mother is Nature. The second mother is Culture. The first mother will never lie... <..> The second mother always understands, resides somewhere outside, prepares a hiding place for their children betrayed by the first mother. The second mother weaves mirages, treats to candies, teaches to avoid the truth of feelings, involuntary reactions, strong emotions... $<\ldots>$ Mothers usually get on well, but sometimes they reach each other's throat. They fight like bitches. And their fight arena is their child. Whichever mother wins, the arena loses. Arena's wounds hurt, sometimes it bites the nails to blood, puts a knife between thighs, forgets to flush water, suffers from sleepwalking.

${ }^{7}$ Someone is trying to sit on the bench, Shimon rushes to draw in his excited mind, maybe even with prefix self-, he self-draws as if breathes in, like an anteater draws in an ant, to a prison, to a funnel. Now, he's pulled himself together again, again in an uncomfortable and unusual cell - only from this figuratively red-hot place, through that self was he able to communicate with others.

${ }^{8}$ Sleepy Bruno came into the kitchen, took a quick look at an empty table and smiled. He smiled as if everything had returned to the norm.
} 


\section{Ukrainian sense. 2020. ISSN 2313-4437}

produced by comparing the plot or a particular character with other texts that have become cultural artifacts.

To fiction texts which contain multidimensional irony belongs Frutchen - a short story by Tymofiy Havryliv. Its structure ironically reflects Roland Barthes's explanation of the hermeneutic code found in his $S / Z$, which is a landmark of deconstructivism. The hermeneutic code as a total of textual units seeking to formulate a question and prepare an answer (a reference to various circumstances able to impact the question or postpone the answer) is explained by the French scholar through the example of Sarrasine analysis: "The title raises a question: What is Sarrasine? A noun? A name? A thing? A man? A woman? This question will not be answered until much later...<..> Thus, the title Sarrasine initiates the first step in a sequence which will not be completed until No 153 ..." (Barthes, 2002: 17).

T. Havryliv likewise titles his work with the name whose wording triggers various associations, yet does not ensure any certainty as to any of those. The author in a sophisticated way guides the reader through a search for the answer to the question what frutchen is, simultaneously imitating various academic search techniques, which gradually transforms into formula-based literary genres. The narrator of T. Havryliv's short story step by step convinces the reader of the fact that frutchen is not a living being, nor a bird, nor a fish, nor an animal, nor a diamond ring in the jewelry shop window, nor seven more option the last one being followed by ellipsis. Similarly to R. Barthes, he takes tiny steps from comparing the sound and the spelling of a word (unlike Barthes, he concludes that it by no means affects the understanding of what frutchen is) to making parallels with a person and their life (anthropologization), to spotting similarity (he compares it with flowers and sun as an enjoyment-bringing event, and gravity. As to gravity, here we can see irony related to the inverse determination principle, whereby the event significance is determined based on its consequences. T. Havryliv ironizes over what would have happened, had there been no Newton: “Тоді все виглядало би по-іншому - людина літала би разом із деревами, носорогами та будинками, годівниці для птахів ненастанно гойдалися б, а книжки не затримувалися би на полицях бібліотек"9 (Havryliv, 2010: 19). This way, the text designed as a deconstructivist academic research gains nonsense which can be extrapolated to R. Barthes's text based on inverse association), to emphasizing pragmatic aspects (the existence of frutchen under certain laws of physics may draw attention of the representatives of both "sciences" and "arts", as it is worth being represented in fiction texts. Hence, both aspects are important and have to constitute school curricula, including electives. Yet, while the narrator keeps hiding what frutchen is, a physics teacher asks students hoping that this will be passed to students' parents and acquaintances. The very text about frutchen is mentioned as a learning material for a school special course, even though it is not yet a part of reading/writing and its introduction will involve issuing an educational manual and receiving the ministry's stamp of approval) and proposing practical application (to replace with frutchen the system of encouragement and government awards) with gradual addition of the information about frutchen's impact on human body: two or three ones are necessary to feel good and cheerful. Similarly to R. Barthes, each word has a special charge. At this stage of story perception, the reader is the most likely to understand the word "cheerful" in relation to emotions triggered by frutchen possession/consumption; on the other hand, when the reader is offered "the truth", they will understand that the word is used literally, not figuratively, and has to do with color diversity in frutchen's decoration.

Following all these intellectual and image-bound procedures, the reader finds out that frutchen is a fruit cake, which may vary depending on the dough filling. Yet, receiving the answer to the question placed in the text did not exhaust the plot, as it features other characters - a person observing frutchen and the narrator observing how this person has been observed by others. Hence, irony is applied to the entire process of fiction narration combined with pseudo-academic narration (featuring the devices of metatextual narration, imaginary dialogue with potential readers as

\footnotetext{
${ }^{9}$ Everything would have looked different - a human would have flown together with trees, rhinos and houses; bird feeders would have been constantly swinging, and books wouldn't have stayed on library shelves.
} 


\section{Ukrainian sense. 2020. ISSN 2313-4437}

witnesses to author's speculations and narrator's self-dialogue) and to uncovering to the reader the personality of the character (the textual role of the unknown character has changed a couple of times: persecuted - persecutor - persecuted?; decoding the unknown by third party observers based on its behavior and appearance is done in several stages: a criminal, a spy, a terrorist, an alcohol addict, a homeless - by the way, all these are typical movie characters targeting mass audience).

The narrator occupies a key position in the story, as it is him who determines the narrative focus direction and uncovers to the reader the secret of frutchen. Yet, the narrator does not carry the full knowledge in the text; he seems to be watching from the side of a particular character who acts as a subsequent narrative focus. At first, it is him, whom the "academic" word belongs to. Then, the narrative focus shifts to subway security guards, who discuss an unknown person and their future action in front of the security camera. When the guards realized that it was a homeless, they lost their interest towards him. In this case, the narrative focus is placed on the unknown person, which can hardly be identified with the narrator as it puts a bunch of questions similar in style to those that enhance audience's interest to the upcoming movie episodes and imply options for further plot development: "Чому невідомий пішов? Невже він зараз таки попрямує до вітрини? Невже сила фрутхенової гравітації здолала його, який так довго чинив ій опір? <..> невже це він витягає сотенну банкноту з м'якого шкіряного поляриса, з кишеньок якого несміливодопитливо визирують кредитні й страхувальні картки i світлина, яку не пощастило роздивитися, оскільки він повернувся боком, а зазирати через плече не випадає?" 10 (Havryliv, 2010: 23). The total makes 10 questions among which, there are those that question the guards' conclusion as to the status of the unknown person they had been watching over, to be more specific, a mismatch between the homeless's appearance and the content of his pockets and a remark that the homeless is a foreigner.

Following the narrator's discussion with readers and himself about the further destiny of the unknown person, the narrative focus is again placed on the latter. The narration adopts new terminology. The events are perceived through representing the unknown person as persecuted and a persecutor, which enables us to think about another observer. The story ends unexpectedly: the unknown person follows a young couple out of the subway, chases them at the crossroad (as the main narrator hints, he has been following them to take away frutchen he could not afford), but turns around and follows a different direction and behaves as if being persecuted himself, spots occasional people on his way, the last one being a woman who had just left the bank and taken for a customer. Such watchfulness and attentiveness make us think that the next "episode" will contain a bank robbery, or the plot will be developed in a spy or a criminal way - in any case, this is expected to be an action. The final utterance confirms this viewpoint: "Йди спокійно, засранцю, ніщо тобі не загрожує" "Havryliv, 2010: 28). This phrase is unlikely to belong to the intelligent narrator who started the story. The word "asshole" was used twice by one of the subway security guards, but the phrase itself belongs to another observer - the high-level narrator who reported on others and who had no idea about him.

A complex system of narrators and narration in the analyzed story creates multidimensional irony over the theme, forms, norms of fiction and academic presentation, principles of structuring formula-based texts. The text externally offers a linear presentation, which alters between the plans of narrative (focusing on frutchen and the unknown person) and narration (narrator's thoughts and his story about frutchen); however, "deconstructivist" analysis promoted by the idea of a potential link between the analyzed fiction text and R. Barthes's text, makes it possible to identify multiple interpretations and multiple plot development options, which depend on constant amplification of communicative lines expressed during the analysis.

\footnotetext{
${ }^{10}$ Why is the unknown gone? Is he heading for the shop-window? Did the power of frutchen gravity defeat him had resisted it for such a while? $\langle\ldots\rangle$ is he really taking out a one-hundred banknote of soft leather Polaris, which awkwardly demonstrated credit and insurance cards and a picture they didn't have a chance to see as he turned his side, and looking over the shoulder is not an option?

${ }^{11}$ Off you go, asshole, you're under no threat.
} 


\section{Ukrainian sense. 2020. ISSN 2313-4437}

Conclusions. The meaning vector of Ignacy Karpowicz's narrative strategy in his Ości tends to create a peculiar range of polysemy (wieloznaczn-ość), which, among other meanings, is implied in the book title. The title's polysemy transits to the level on non-pronounced, to "ness", which indicates a leftover from the verbalized. The intertextually-formal aspect of the irony determines the novel's receptive strategy. The reader has to read characters' "true" story following the picture provided by the narrator. The reader is offered a detailed picture of their thinking and self-analysis. The author seems to be kidding at the techniques innate in formula-based genres, inheriting them and breaking stereotypes at the same time. An ironic effect is produced via hints, understatements, unexpected approaches to representation. The "narrative" irony is combined with irony over contemporary trends in literary studies and postmodern philosophical discussions. Irony becomes not only polysemic, but multidimensional: it unfolds on the surface of the text like language and narrative game and alludes to other texts, "widely known in narrow circles", emphasizing the need for professional interpretation. Frutchen by Tymofiy Havryliv is explored in terms of conceptual comparison with $S / Z$ by R. Barthes, where he outlines the principles of deconstructive analysis. T. Havryliv seems to be following reverse logic; he constructs his text as a reflection of the way to read a hermeneutic code declared by R. Barthes, he walks his reader through all "twists" of deconstructive thinking. A complex system of narrators and narrative in the story makes a multidimensional irony over the theme, forms and norms of academic presentation and formulabased fiction texts. In future, it is necessary to focus on the correlation between laughter and nonlaughter poetics to emphasize ironic postmodern thinking in fiction texts.

\section{REFERENCES}

(ak). (2013). Ignacy Karpowicz - Ości, czyli powieść o wysokiej jakości [Fish Bones, or a High-Quality Novel]. Kurier Poranny [Morning Courier]. Retrieved from: http://www.poranny.pl/ kultura/recenzje/art/5539096/ [in Polish].

Andrychyk, M. (2014). Intelektual jak heroj ukrains'koi prozy 90-kh rokiv XX stolittia [An Intellectual as a Hero of Ukrainian Prose of the Late XX century]. Lviv: Pyramida [in Ukrainian].

Barthes, R. (2002). S / Z. New York, Blackwell Publishing.

Czapliński, P. Ości: dobra nowina Karpowicza [Fish Bones: Good News from Karpowicz]. Gazeta Wyborcza - Wyborcza Newspaper. Retrieved from: http://wyborcza.pl/1,75410,14075455 [in Polish].

Eko, U. (2000). Zamietki na polyah "Imieni rozy" [The Name of the Rose: Marginal Notes]. In: Eko, U. Imia rozy [The Name of the Rose] (pp. 596-644). Sankt-Peterburg: Simpozium [in Russian].

Havryliv, T. (2010). Frutchen [Frutchen]. In: Charivnyi svit. Teper [The Magic World. Nowadays] (pp. 14-28). Lviv: Kalvaria [in Ukrainian].

Karpowicz, I. (2014). Ości [Fish Bones]. Kraków: Wydawnictwo Literackie [in Polish].

Zozulya, O. (2014). Ironichni ta parodiyni modusy postmodernists'koho dyskursu: suchasni pohlyady ta interpretatsii [Irony and parody modes in postmodern discourse: contemporary approaches and interpretations]. Literaturoznavstvo. Folklorystyka. Kulturolohiia [Literature. Folklore. Cultural Studies] (pp. 76-85). Cherkasy: Vudabets' Chabanenko Yu. A. [in Ukrainian].

\section{Анотація}

Постановка проблеми: Іронія $і$ сміх у постмодерністській карнавальній прозі пов'язані між собою, але не взаємозумовлені. Традичійно іронію визначають у іï спрямованості на досягнення сміху, однак постмодерністська іронія може бути несмішною. Ії домінантна ознака - двозначність смислу, що витворюється завдяки дистанції між сказаним $i$ замовчаним. Іронію простежено як в аспекті смислоутворення (i тоді важить $i$ повідомлення, і сам код, а окремі фрагменти іронічного висловлювання стають значущими), так і інтертекстуально-формальний аспект іронії як художнього прийому й виразника постмодерної тотальної іронічної свідомості. 


\section{Ukrainian sense. 2020. ISSN 2313-4437}

Мета статmі - простежити наративні форми домінації іронічної гри як способу художнього викладу й композищійного принцииу в прозових текстах письменниківпостмодерністів.

Для дослідження використано методи наратологічного аналізу та рецептивної естетики.

Основні результати дослідження. Смисловий вектор наративної стратегї Ігнація Карповича в романі “Риб'ячі кістки” спрямований на витворення особливого діапазону багатозначності (wieloznaczn-ości), що серед інших значень закладено в назві твору. Багатозначність назви переходить у ранг невисловлюваного, в “ість", чим сигналізує залишок від ословленого. Інтертекстуально-формальний аспект іронії визначає рецептивну стратегію роману. Читач повинен за наданою наратором картинкою відчитати "реальну" історію персонажів. Перед читачем розгорнуто розлогу картину нюансів їхнього мислення й самоаналізу. Автор ніби жартує з прийомів формульних жанрів, водночас наслідуючи їх $i$ відходячи від стереотипів. Іронічний ефект виникає завдяки натякам, недомовкам, неочікуваним ракурсам зображення. "Наративну” іронію поєднано з іронією над сучасними тенденціями в літературознавстві та постмодерністськими філософськими дискусіями. Іронія стає не лише неоднозначною, а й багатоплановою: розгортається на поверхні тексту як мовна й наративна гра та відсилає до інших текстів, наголошуючи на потребі фахової інтерпретачіï. Оповідання Тимофія Гавриліва “Фрутхен” розглянуто в концептуальному зіставленні з пращею “ $S$ / Z” P. Барта, у якій викладені принципи деконструктивістського аналізу. Т. Гаврилів ніби йде логікою зворотного порядку, він конструює свій текст як відбиття проголошеного Р. Бартом шляху відчитування герменевтичного коду, проводить свого читача всіма “зигзагами" деконструктивістського мислення. Складна система нараторів $і$ нараиії в оповіданні є багатовимірною іронією над тематикою, формами, нормами наукового викладу та художніх формульних текстів.

Висновки і перспективи. Окреслено форми несміхової іронії, простежено ї̈ вплив на утворення багатозначності постмодерного художнього тексту. Зазначено також наративні прийоми та рецептивні стратегії, використані авторами. У подальшому варто зосередитися на співвідношенні сміхової та несміхової поетик для увиразнення іронічного постмодерного мислення в художніх текстах.

Ключові слова: постмодерна проза, іронічна свідомість, іронія як прийом, несміхова іронія, іронічна гра, іронічний ефект, композиційний принцип, смислоутворення.

\section{Abstract}

Background. Irony and laughter in postmodern carnival prose are interrelated, yet not interdependent. Irony is traditionally defined in terms of its laughter-causing trend; however, postmodern irony can be not funny. Its predominating sign is meaning ambiguity resulting from the gap between pronounced and non-pronounced. Irony is traced both in a meaning-shaping aspect (in which case both a message, and a code matter, and separate fragments of an ironic utterance gain significance), and in an intertextually-formal aspect of irony as a stylistic device and an expression of the overall postmodern ironic mind.

Purpose. The article seeks to trace the narrative forms of the ironic game's domination as a narrative pattern and composition principle of the prose by postmodern writers.

The research employs the methods of narrative analysis and receptive aesthetics.

Results. The meaning vector of Ignacy Karpowicz's narrative strategy in his Ości tends to create a peculiar range of polysemy, which, among other meanings, is implied in the book title. The title's polysemy transits to the level on non-pronounced, to "ness", which indicates a leftover from the verbalized. The intertextually-formal aspect of the irony determines the novel's receptive strategy. The reader has to read characters" "true" story following the picture provided by the narrator. The reader is offered a detailed picture of their thinking and self-analysis. The author seems to be kidding at the techniques innate in formula-based genres, inheriting them and breaking stereotypes at the same time. An ironic effect is produced via hints, understatements, unexpected 


\section{Ukrainian sense. 2020. ISSN 2313-4437}

approaches to representation. The "narrative" irony is combined with irony over contemporary trends in literary studies and postmodern philosophical discussions. Irony becomes not only polysemic, but multidimensional: it unfolds on the surface of the text like language and narrative game and alludes to other texts, emphasizing the need for professional interpretation. Frutchen by Tymofiy Havryliv is explored in terms of conceptual comparison with " $\mathrm{S} / \mathrm{Z}$ " by R. Barthes, where he outlines the principles of deconstructive analysis. T. Havryliv seems to be following reverse logic; he constructs his text as a reflection of the way to read a hermeneutic code declared by $R$. Barthes, he walks his reader through all "twists" of deconstructive thinking. A complex system of narrators and narrative in the story makes a multidimensional irony over the theme, forms and norms of academic presentation and formula-based fiction texts.

Discussion. The article outlines the forms of non-laughter irony and traces its impact on the creation of polysemy of the postmodern fiction text. Besides, it indicates narrative devices and receptive strategies used by the authors. In future, it is necessary to focus on the correlation between laughter and non-laughter poetics to emphasize ironic postmodern thinking in fiction texts.

Keywords: postmodern prose, ironic mind, irony as a device, ironic game, ironic effect, composition principle, meaning construction. 